\title{
DESERT, PUNISHMENT, AND CRIMINAL RESPONSIBILITY
}

\author{
LLOYD L. WEINREB*
}

\section{INTRODUCTION}

The crucial element in any theory of punishment is its treatment of the matter of desert. For the retributivist, desert is the sole basis on which punishment properly is imposed; he is accordingly obliged to explain how desert attaches and, more particularly, how it is translated into a measurement of punishment. Those have proved to be difficult tasks. Objectors to the retributivist position not only question whether a person can be said to be guilty in the sense required by desert. They question also whether desert, if it is a meaningful concept, by itself justifies the deliberate infliction of pain; if pain itself is not a good and no good consequences are in view, they argue, the question can have only one answer. To fortify those questions, they challenge retributivists to make their position concrete and specify what punishment attaches by way of desert to specific crimes. ${ }^{1}$

Utilitarians, on the other hand, have the greatest difficulty not defending desert but getting rid of it. They are asked if they can even explain the concept of punishment, as distinguished from other kinds of public obligation, without reference to desert. If desert is not relevant, why would they not, to attain a desirable end, punish the innocent, that is, those who do not deserve to be punished? In response, utilitarians proffer elaborate arguments to show the instrumental value of punishing the guilty and only them; but tacitly or even explicitly, the real proof of the correctness of their arguments is that the results are consistent with considerations of desert, which is enough to undermine the conclusion the arguments are intended to support. ${ }^{2}$

Copyright $(\mathcal{C} 1986$ by Lloyd L. Weinreb

* Professor of Law, Harvard Law School.

1. The justification of punishment has been discussed extensively in philosophical and legal writing. Two excellent survey articles, which together suggest the range of the literature are by Benn, Punishment, in 7 The Encyclopedia of Philosophy 29 (1967), and Greenawalt, Punishment, in 4 Encyclopedia of Crime and Justice 1336 (1983), reprinted in 74 J. Crim. L. \& Criminology 343 (1983). Both contain useful bibliographies.

Although the summary statements of the retributive and utilitarian positions that $I$ have provided here scarcely do justice to the subtlety of the arguments on both sides, no purpose would be served by a more thorough exposition. The fine distinctions that are made are all efforts to account satisfactorily for desert.

2. See Rawls, Two Concepts of Rules, 64 Phil. Rev. 3 (1955); $c$. H.L.A. Hart, Punishment and REsPonsibility 18-22 (1968). In a highly regarded book, Herbert Packer argued forcefully that the only justification for criminal punishment is utilitarian: the prevention of crime. H. PACKER, ThE 
To end the impasse, a variety of composite theories have been proposed. ${ }^{3}$ Those who favor the use of punishment to reform or rehabilitate the criminal may recognize that only those who so deserve may be punished but urge that utilitarian considerations ought to determine the extent of punishment. If desert is a condition of punishment, it is not credible that it operates like a sluice gate; for we all know that pain can be greater or less, and no explanation is given why it should be regarded as indivisible so long as it is deserved. The suggestion that the individual desert of the traffic offender and the murderer or, less dramatically, the petty shoplifter and the bank robber, has no comparative bearing on their punishment, provided it has been established that they deserve to be punished at all, makes no sense. ${ }^{4}$

Limits of the Criminal Sanction 35-70 (1968). ("The case for an essentially preventive view of the function of criminal law is unanswerable; anything else is the merest savagery." Id. at 66.) According to Packer, if we were certain that the costs of punishment, including the harm inflicted on those who are punished as well as more general societal and individual costs, were less than the benefits, considerations of culpability - blameworthiness for commission of an offense-might be disregarded. But the utilitarian calculus is not certain, and for that reason there are instrumental reasons to require culpability as a condition of punishment. Id. at 62-70.

[A] purely preventive view, reinforced as that view is today by a scientific and deterministic attitude toward the possibilities for controlling human conduct, carries the danger that singleminded pursuit of the goal of crime prevention will slight and in the end defeat the ultimate goal of law in a free society, which is to liberate rather than to restrain. Human autonomy is an illusion if we make it conditional on human perfection.

Id. at 66 . Packer straddles the question whether uncertainty about how to achieve utilitarian goals should be regarded simply as our current state of knowledge or as an a priori assumption.

As we find ourselves gaining more nearly exact knowledge about the sources and control of deviant behavior, the pressure from the behavioral position upon this rationale will become very strong and may prove to be irresistible. The more confidently we can predict behavior and the more subtly we can control it, the more powerful will be the temptation to relax the constraints that inhibit us at present from aggressively intervening in the lives of individuals in the name of crime prevention. But the millennium will not announce itself with unmistakable clarity. And skeptics about its advent may then as now find some merit in a limiting rationale for the criminal sanction.

Id. The value of human autonomy, on which Packer's argument finally rests, requires recognition of desert, not simply as a fence against excessive utilitarian zeal, but because desert is part of the meaning of autonomy. See infra pp. 74-75.

3. Occasionally it is suggested that each of the two theories may provide a separate and independent, sufficient justification for punishment. See Flew, The Justification of Punishment, 29 PHIL. 291, 306-07 (1954); Mundle, Punishment and Desert, 4 PHIL. Q. 216, 228 (1954).

4. Packer's theory is not strictly subject to this objection because he relies on desert not to justify the imposition of punishment but to limit its imposition even though it may be justified. See $\mathbf{H}$. PACKER, supra note 2. But if, as he says, "once a decision to punish has been made and justified on other grounds, the rehabilitative ideal should be fully used in deciding what kinds of punishment should be imposed," id. at 67 , the protection afforded by his limiting principle is likely to be very weak indeed. That reinforces the conclusion that the basis for the principle is not entirely instrumental. Insofar as it is not instrumental, it is subject to the objection.

See also Morris \& Miller, Predictions of Dangerousness, 6 CRIME AND Justice 1 (1985). The authors argue that predictions of dangerousness are a proper basis of punishment provided the punishment does not exceed "what would be justified independent of that prediction. Thus, concepts of 'desert' define the upper limits of allowable punishment." Id. at 6 . They say that we are ordinarily unable to state with precision what is a "just" [i.e., deserved] punishment; the most we can do is conclude that a punishment is "not unjust." Since there is usually a range of punishments that are not unjust, the utilitarian consideration of dangerousness has room within which to operate. Id. at 37. Although Morris and Miller assert, not without reason, that the practical effect of full implementation of their proposals would be to restrict the implicit or explicit reliance on predictions of dangerousness in the actual criminal process, $i d$. at 38, their theoretical model makes one skeptical of how significant their 
Another kind of composite theory, which probably comes closest to the reflective judgment of most people, is that utilitarian considerations ought to determine what conduct is criminal but that considerations of desert restrict the imposition and extent of punishment in a particular case. ${ }^{5}$ Such a position appears to accommodate what is most persuasive about retributive and utilitarian theories. By separating justification of the law from justification of punishment under the law, it avoids the useless infliction of punishment and, at the same time, punishes according to desert. The proposed separation, however, is illusory. For it is the law's definition of guilt that determines who will be punished. When utility and individual desert do not coincide, one or the other of the theory's distinct principles must give way. If it were shown, for example, that utilitarian values would be served by the punishment of persons who engage in certain conduct involuntarily-say, while sleepwalking or drugged-under this theory, ought the law provide that such involuntary conduct is a crime? If so, does the theory allow a person who commits such a crime to be punished? Evidently it is intended that utilitarian considerations govern only the kinds of conduct that are criminal and not the exculpatory (or inculpatory) significance of the actor's individual circumstances, which depends on desert. That limitation gives away everything to the retributive view, no matter what the basis on which some kinds of conduct are made criminal and not others. ${ }^{6}$

The inconclusiveness of the theoretical debate has noticeably little effect on practical issues. Although the punishment (or absence of punishment) in particular cases and the extent and manner of punishments generally arouse controversy, it usually turns out that if a person deserves to be punished, there are good consequential reasons to punish him; and if there are good

limiting principle of desert really is. Their program could be put into effect only if we were able to predict accurately. Against the weight of well-supported empirical predictions developed for that purpose, how much force would the notion of an upper limit of not unjust punishment have?

5. Among those who have espoused some version of this position are: H.L.A. HART, supra note 2; Greenawalt, supra note 1; Rawls, supra note 2.

6. Oddly, the point is brought out most clearly in J.D. Mabbott's justly famous article, Punishment, 48 MIND 152 (1939), in which he rejects all utilitarian justifications of punishment. Mabbott argues that the connection between punishment and crime is all that need be considered. "The only justification for punishing any man is that he has broken a law." Id. at 158 . While he is prepared to allow utilitarian considerations to enter into the formation of the law, that issue, he says, is altogether irrelevant to the question of punishment. As for desert, he regards it simply as a matter of whether the law has been broken. Mabbott described his theory as retributive, and it is generally so regarded. But see Flew, supra note 3, at 298-306. If anything, it is rejected as too exclusively retributive. In fact, however, it is on its own terms neither retributive nor utilitarian. It requires neither kind of justification. According to Mabbott's theory, if the law were the product of an altogether irrational process, the fact of violation would still "justify" punishment of the violator. Mabbott is correct, I believe, in denying that utilitarian considerations are essential to a justification of punishment. He is able to eliminate direct consideration of desert as well only because he tacitly assumes that for utilitarian or other reasons, the law will not inculpate someone who is not responsible for his conduct.

The requirement that conduct not be declared criminal except on utilitarian grounds excludes the possibility that crime will be defined according to a dogmatic notion of desert unrelated to the humanly good-equated with sin, as it were. But retributive theories rarely include such elements anymore and certainly need not. 
consequential reasons to punish him, that is what he deserves. ${ }^{7}$ So whatever one's theory, the outcome is about the same. The short explanation for this happy coincidence is that, for whatever reason, criminal law is concerned largely with intentional conduct. Since desert attaches most easily to such conduct, which also can be deterred by the threat of punishment, desert and utility coincide.

The slight practical importance of theories of punishment is illustrated in another way by a small number of persistent doctrinal problems in the criminal law, old chestnuts that keep first-year classes in a state of suspense and are discussed repeatedly in the literature without resolution. Their common element is that a person's liability to be punished or the extent of his punishment is affected by a circumstance beyond his control. Included among such cases are those in which the law provides that punishment be greater or less according to the seriousness of the harm, which may vary independently of the actor's conduct: felony murder, misdemeanormanslaughter and negligent homicide generally, and fully executed, failed attempts. Included also are cases in which the occasion for conduct that makes a person liable is an extraordinary situation not of his own making and the situation itself fully explains his conduct: self-defense against an "innocent aggressor" or an act necessary to preserve oneself that unavoidably exposes another person to the same peril. Also, cases in which the actor's liability depends on the fault or absence of fault of the victim: homicide provoked by the victim or by someone other than the victim, or defense of a third person who is or is not the person originally at fault. ${ }^{8}$ The difficulty of these cases is not that the applications of the retributive and utilitarian theories are in conflict. On the contrary, the theories point in the same direction; only this time neither of the theories justifies the outcomes that the doctrines dictate. The peculiar, troubling feature of the cases is that the doctrines persist, despite the absence of justification according to both theories.

In view of the intractability as well as the practical irrelevance of the abstract issue, it is perhaps not surprising that the theory of punishment is usually treated as a philosophical digression from the main concerns of the criminal law, as if we were clear about when it is correct to punish even if we

7. Greenawalt observes shrewdly:

Theories of justification are often built with existing practices in mind and do not usually stray too far from the reflective moral views of ordinary citizens. The fact that sharply divergent philosophical theories can have closely similar implications across a broad range of actual practices is less a startling coincidence than a product of the existential basis on which those theories are constructed.

Greenawalt, supra note 1, at 1345, reprinted in $74 \mathrm{~J}$. CRIM. L. \& CRIMINOLoGY at 360-61.

8. There are other types of cases that fall more or less within the same description, although those that I have mentioned are the most obvious and important. For a thorough review of such cases, see Schulhofer, Harm and Punishment: A Critique of Emphasis on the Results of Conduct in the Criminal Law, 122 U. PA. L. Rev. 1497 (1974). 
cannot sort out exactly why it is correct. 9 The inability of the most widely held composite theory to maintain a separation between declaring when conduct is criminal and imposing punishment illustrates, however, that within the criminal law the theory by which punishment is justified must be determinative of the fundamental issue of criminal responsibility. Ordinarily, the issue is presented in the context of a specific defense, like insanity or duress; and it is discussed with relation to the specific facts in terms that are not limited to criminal law: causation, voluntariness, intent, and so forth. The general theoretical justification of punishment may not appear to be immediately relevant. But whatever relationship there may be between responsibility and punishment more generally, criminal responsibility renders one susceptible to punishment. A theory of criminal responsibility must literally be a theory of punishment. And if the problem of desert is central to the latter it must likewise be central to the former.

There is reason to believe, therefore, that closer attention to the matter of desert and its relation to punishment will shed light on general and specific doctrinal problems of the criminal law. Of particular interest in that connection is the apparent disregard of considerations of desert in the resolution of concrete issues despite its controlling significance abstractly. If an explanation can be found for those doctrines that persist despite a lack of justification on either retributive or utilitarian grounds, it may help to account also for criminal responsibility in the more usual case, where both doctrines appear to provide the justification independently but inconsistently.

The debate about punishment harbors an ambiguity related to the above that is generally overlooked, and which seems to me critical. It is seldom clear whether punishment is conceived as a strict implication of desert, so that "deserves to be punished" is a unitary, albeit complex, idea, or as a distinct and separable consequence of desert, so that one could properly regard a person as deserving of punishment without answering the question whether he ought to be punished. Proponents of the retributivist view sometimes seem to believe that what they have to defend is not the criminal's desert as such but punishment, more particularly the painful aspect of punishment. And opponents sometimes sound as though they do not object to the idea of the criminal's desert but only to the useless infliction of pain as a consequence; they might agree that abstractly a person deserves to be punished but disagree about carrying out the punishment if there are not utilitarian reasons for doing so. ${ }^{10}$

A similar ambiguity may often be found in statements of the relationship between responsibility and desert. Appearing to concede that the criminal is responsible for his conduct, or at least not arguing that he is not, the

9. That is not to say that the philosophers or the more philosophic-minded of the legal writers have not made the connection. See, e.g., Kadish, Complicity, Cause and Blame: A Study in the Interpretation of Doctrine, 73 Calif. L. REv. 323 (1985).

10. There are additional questions about the imposition of punishment, such as who has authority to punish. The utilitarian objection that I am considering here is independent of those questions. 
utilitarian may assert that nothing follows about the criminal's desert; he may claim, indeed, that a reference to desert is either only a curious way of talking about responsibility or is meaningless altogether. ${ }^{11}$ In response, the retributivist may find himself defending what looks like a move from responsibility to desert. Once again, it may not be clear whether the retributivist believes that desert follows unavoidably from responsibility or is something additional, which needs to be defended and can be rejected independently. ${ }^{12}$

The conception of punishment as separable from desert is, I believe, a mistake, as is the conception of desert as separable from responsibility. Doubts about punishment for crime that are expressed as doubts about the correctness of inflicting pain uselessly are doubts about desert itself. If it were clear that a person deserved to be punished, the fact that punishing him would require the infliction of pain would not itself be a reason not to punish him, even though the punishment would predictably do no good. Equally, if it were clear that a person was responsible for a wrong, his desert (and therefore the propriety of punishment) would follow without more. Doubts about a person's desert are, at bottom, doubts about his responsibility from a moral point of view. ${ }^{13}$

There is, therefore, a relationship between responsibility and punishment, mediated by the idea of desert, which requires no additional argument. Thus

11. The overlooked ambiguity spares the utilitarian the burden of explaining what responsibility without desert means. I do not believe that the idea of responsibility without desert can be sustained. See infra p. 74.

12. In each case, the appearance of separability is fortified by a question that we are unable to answer satisfactorily even though desert seems to have been established in principle. Sometimes, pace Kant, one may question whether those having authority to punish ought to carry out a deserved punishment, because of strong utilitarian considerations to the contrary. The difference between cosmic justice and human justice, which in this context Kant disregards, is that the latter requires a decision; justice is not the only human goal, and another goal can sometimes be preferred without overthrowing justice altogether (as a departure from it would overthrow justice as part of the determinate natural order). That makes it easier to believe that desert is not by itself a reason to punish when we do. The apparent separability of desert and responsibility is fortified by our inability to specify what precisely a person deserves, even though the facts establishing his responsibility are undisputed.

13. It follows that I disagree with the assertion that strict retributive justifications for punishment "can be shown to be either denials of the need to justify it, or mere reiterations of the principle to be justified, or disguised utilitarianism." Benn, An Approach to the Problems of Punishment, 33 Phil. 325, 327 (1958). See also H. Packer, supra note 2, at 38-39 where he states that the argument "that it is right for punishment to be inflicted on persons who commit crimes ... has no useful place in a theory of justification for punishment, because what it expresses is nothing more than a dogma, unverifiable and on its face implausible." Benn observes: "Appeals to authority apart, we can provide ultimate justification for rules and institutions, only by showing that they yield advantages." Benn, supra, note 1, at 326 (footnote omitted). He says also: "[R]etributive justifications in general are unsatisfactory for the very reason that they refuse to look to the consequences of a rule, thereby denying a necessary part of the procedure for justifying it." Id. at 329. Unless he is only stipulating what he means by justification, which is unlikely, Benn seems here to assume the very point at issue. One needs to distinguish at least between justification on a basis other than consequences and a refusal to consider consequences, however serious, at all. The former does not require the latter. I argue in this article that punishment for desert is an implication of an aspect of the human condition, freedom and responsibility, that is not open to question (although, as I also argue, it is antinomic). The justification of retributive theories is simply our recognition of human responsibility. 
far, the retributive position is correct. At the same time, the causally determinate background of human action undermines our conclusions about individual responsibility and, equally and inescapably, undermines desert as a basis for punishment. To the extent that they depend on rejection of retributivism, the utilitarian's consequential arguments are sustained. The two positions are contradictory, and the effort to join them in a unified theory of punishment must fail, even though each considered separately may point in the same direction as the other.

In order to overcome the contradiction, one would have to adopt the ontological premise of normative natural order-that is, that the causally determinate background of our actions is itself according to our desert. Such a premise, however, contradicts the opposition between freedom and cause or, as it may be put, the separation between normative and descriptive discourse- "ought" and "is." The substantive doctrines of the criminal law indicate that the separation, beyond challenge abstractly, is not always maintained in our experience.

It is the purpose of this article to elaborate and explain those very abstract and, in some respects, counter-intuitive propositions. Section two of the article contains some ruminations about the connection between responsibility and desert generally. In section three, I discuss criminal responsibility and the problematic doctrines of the law, in which the connection between responsibility and desert, as it is ordinarily understood, is weak. In section four, I describe how these problems of crime and punishment would be viewed from the normative ontological perspective.

It is not part of my purpose to convince anyone that that perspective is correct. No more than anyone else, can I make sense of the claim that "what is, because it is, ought to be," at least without the aid of some theological or other metaphysical hypothesis that puts the matter beyond debate. Rather, the normative ontological perspective accounts, on its own terms, for a fundamental aspect of the organization of our experience-human freedom, responsibility, and desert-which is not itself open to question. Furthermore, the manner in which we now account for that aspect of our experience, which preserves the separation between what is and what ought to be, is subject to the same objections, to the same extent, as the perspective that we reject. All that renders the latter acceptable to us, and the former not, is the conventional pattern of our thought. These conclusions do not validate the utilitarian resolution of the problem of punishment. For, as I have said, freedom and responsibility, and with them, desert, are given directly in our experience.

\section{II}

\section{RESPONSIBILITY AND DESERT}

It is usually the case when a judgment about a person's desert is questioned that the explanation offered to defend the judgment is descriptive. Asked to explain an assertion that Harry deserves to be punished, one is likely 
to respond with just a description, which may be simple or elaborate, of what Harry did. There is no logical trap waiting to be sprung in that small observation. It reflects, I think, only that we are likely to withhold a judgment about desert unless we are confident of the underlying normative principle, which we expect others also to perceive and accept. If someone questions the judgment, we assume that he lacks information about the facts, not that he is unaware of or doubtful about the principle. So, asked to explain why Harry deserves to be punished, one is likely to say, "He left her bruised and battered," or "He promised to do otherwise," rather than "It is wrong to beat up people," or "People shouldn't make promises unless they mean to keep them." Of course, after hearing a description of Harry's conduct, the questioner might reply, "So what if he did?" The speaker would then have to tender the normative principle; but more than likely, he would be considerably puzzled about the need to do so.

Facts that explain why a person deserves to be punished have to be described in a certain way; or, one may prefer to say, they have to include a certain kind of fact. They must refer to the person as an actor, not simply someone who was affected or someone the effect on whom contributed to other effects. Furthermore, as an actor, he must be presented as responsible for the conduct in question. ${ }^{14}$ So far as desert is concerned, nothing else counts, because only insofar as he is responsible does a normative principle come into play at all. His responsibility need not eliminate from the description reference to other causes without which the event would not have occurred as it did (although it may eliminate some). Harry "started the fire"; just the same, there would have been no fire had there not been a pile of leaves (left, perhaps, by someone else) and a strong wind, not to mention all the other general conditions of combustion.

Although this attribution of responsibility is critical, typically it is not explicit but is built into the description of an event and, unless challenged, taken for granted. Nevertheless, one can challenge an assertion about desert by questioning the implicit attributive element, while agreeing with the normative principle being applied and accepting the factual description in every other respect. Such challenges comprise the whole range of what we call excuses. Sometimes, an excuse goes to the brink of denying that one's conduct caused the event. It suggests that we look elsewhere in the situation for the significant cause and regard the person's involvement as only an attendant condition, a kind of physical link between the cause and the effect. Someone on a bus who bumps into another person, for example, may offer as an excuse, "I was shoved," or, "The bus stopped short," and think that an apology is not strictly in order. Other excuses acknowledge the actor's intention to bring about the result, but deny that he is responsible in the required sense because of some fact about him, which may pertain only to the

14. I rely for the moment on the familiar notion of responsibility that we use all the time without difficulty. It is part of the program of this article to elucidate some aspects of this notion more precisely. 
event in question or more generally: he was "only a child," or was delirious, or was an addict or insane. One may agree that conduct was intentional and that one is responsible for it in general, but deny his responsibility in a particular respect that made it violative of the normative principle. So, one may excuse himself, saying, "I was not thinking about that," or "I thought you wouldn't mind," or "I thought at the time it was the right thing to do." Such excuses may approach a denial that the conduct violated a normative principle at all.

The range of such responsibility-denying excuses is large and may be said to include any explanation that avoids desert except, at one extreme, the denial of any causal connection whatever-the event would have been the same whatever the actor had done-and, at the other, rejection of the underlying normative principle, so that one affirms his responsibility but claims that he deserves well or at least not ill. ${ }^{15}$ For all their concrete variety, whether they focus attention away from the actor or toward some particular aspect of him or his conduct, excuses have a good deal in common. Although, like many descriptive concepts, they may incorporate a reference to an evaluative standard, they purport to describe what is the case; they are cast descriptively rather than prescriptively. Furthermore, although there are identifiable, more or less distinct types of excuse along the range from no causal connection to no moral fault, the types tend to collapse into one another. Responsibility must be for something; unless conduct is an event, a happening that perceptibly alters the state of things, there is nothing to which a normative principle can be applied, and no excuse is necessary or

15. Although the difference between an excuse and a denial of causal responsibility or rejection of a normative principle is one that we recognize and has significance generally, cases at either end of the range of excuses may not easily be labeled as an excuse or something else. One may, for example, respond to an accusation of thoughtlessness toward his sibling, "I am not my brother's keeper." That may be a statement of fact-the law or some other positive code does not make me responsible for my brother's well-being - or it may be a rejection of the implied obligation. Or it may be a bit of both. If the person who responded that way were pressed and he insisted that he had no obligation to look after his brother, the reply, "That's no excuse," would be out of place, because he was not offering an excuse at all; rather he was asserting that he needs no excuse, for his conduct was not at fault. On the other hand, if he were to insist only that he was not legally obligated to look after his brother, that would be an offer of an excuse (of a somewhat special kind) to which the reply might well be, "That's no excuse." At the other end of the range, the denial of causal responsibility, which makes an excuse otiose, may be mixed up with a sort of excuse. For example, a person who is accused of failing to prevent some harm may respond, "I had nothing to do with it," without denying that he was aware of the harm and was able to prevent it; any number of other persons could also have prevented the harm and he was no more implicated than they. His response is perhaps not a denial that someone ought to have acted; it may fit ambiguously between a denial of causal responsibility and a claim that, given the number of other persons on whom the obligation fell equally, he (as well as any other person in his situation) ought to be excused from individual responsibility. The important point for the present purpose is not precisely how a specific exculpatory statement is catalogued, but that there is a category of "excuses": statements that acknowledge both causal responsibility and the normative principle but deny an attribution of desert, on grounds peculiar to the actor's case. See generally Fletcher, The Right and the Reasonable, $98 \mathrm{HARV}$. L. Rev. 949 (1985); Greenawalt, The Perplexing Borders of Justification and Excuse, 84 Colum. L. REV. 1897 (1984) (both discussing the various doctrines known as "excuses" in the criminal law). 
appropriate. ${ }^{16}$ The larger a harm or loss, the more likely we are to look for a human agent and, having found him, the more likely we are to regard him as morally responsible. On the other hand, the greater the moral fault, the more likely we are to identify conduct as the effective cause of whatever harm results; whereas if the fault is small, we are more likely to look around for another cause among the circumstances.

The excuses that we offer and accept help to clarify what we mean by responsibility and desert. They presuppose that a person is responsible for his conduct and desert can attach only insofar as the conduct is selfdetermined, and that whether conduct is self-determined or not is a matter of fact. ${ }^{17}$ An attribution of desert requires that a person have exercised a capacity to direct his actions for himself (even if by taking no action). Also, since an "action" does not consist entirely ${ }^{18}$ of a determination of the will but occurs as an event in the world, it requires a sufficiently stable natural order, a setting of non-self-determining things that respond predictably to events. ${ }^{19}$ Neither of those requirements is, in general, problematic. Without insisting that the capacity for self-determined action is either necessary or sufficient to constitute the category of "persons," it is true at least that the capacity is a central definitional element of the category. ${ }^{20}$ And in fact the two requirements seem like structural conditions of our experience of a world of persons and things. Although we can look behind them in a particular case or perhaps be persuaded to shift an object or type of object from one category to the other, we cannot within our experience question them in principle.

Our practice of making excuses indicates that there is another requirement for an attribution of desert, which stands on very different footing. Unless the

16. That is not to say that one can only be responsible if there is a perceptible harm. One may be responsible for driving recklessly, even though, as it turns out, no one is injured. The idea that it is sinful to lust in one's heart, Matthew 5:28, is not an exception; it regards lust as the effect of an exercise of will.

17. To say that it is a matter of fact is not to say that it is easily ascertained or is observable in a simple way, but that it purports to say what is the case and not what ought to be the case. As I argue below, however, the notion of self-determination is not fully intelligible unless the distinction between fact and value is somehow overcome.

It is more usual to say that conduct must be "voluntary" in order for a person to be responsible, rather than that it must be "self-determined." The criminal law typically refers to voluntariness. E.g., Model Penal Code $\$ 2.01$ (1985). The ambiguity of the concept of voluntariness in this context, which makes it so useful in ordinary discourse (and in the criminal law), makes it less useful here. It may be used to characterize the actor's attitude-willing or unwilling, eager or reluctanttowards conduct for which all would agree he is responsible as well as all the gradations of pressure up to and even including compulsion to act. While the idea of self-determination is not always easily applied, it is more precise and, for reasons explained in this essay, gets at the critical question.

18. Or perhaps at all-? I do not wish to take up the difficult problem involved in the idea of will or a will.

19. That is true even if the action is nothing but a bodily movement. Insofar as there are "mental events," they also are included.

20. A great deal more could be said on that subject. I am not especially troubled by the notion of a "person" who has few, or none, of the characteristics of a human being. Science fiction thrives on such possibilities. Nor am I troubled by the notion of a creature that has all of the other characteristics of a human being but is not a person. Some robots may come close. Still, I do not think that the category of persons could be made independent of such ordinary identifying characteristics altogether. 
capacity to determine one's action is not merely individual but personal in a strong, constitutive sense, an attribution on the basis of how the capacity is exercised seems altogether arbitrary; for the attribution attaches to a particular person and not simply to a person or to any person. It is to avoid just such arbitrariness that we reject immediately vicarious liability for the acts of another, if there is nothing to connect the person in question and the actor. ${ }^{21}$ So far as the law is concerned, of course, there is nothing vicarious about Smith's liability, say, for homicide if it is Smith who fired the fatal shot. The very person who pulled the trigger is the person who goes to prison. We are there regarding Smith, however, not simply as an autonomous self, a selfdetermining, individual entity, but as a person in the ordinary sense, with concrete attributes and an actual history: height, weight, hair color, intellect, habits, desires, upbringing, education, job experience, family relationshipsthe whole lot. As to all that, he is not autonomous at all; on the contrary, he simply is who he is, Smith and no one else. (If his present attributes are the effects of his actions in the past, those actions were taken by Smith as he was then.) And it is clear that those nonautonomously acquired attributes are implicated in the actual exercise of the capacity for self-determination that calls forth the attribution of desert. Yet, non-autonomous factors in a situation are just what we regularly allow as excuses.

So we begin a retreat. It is not personal characteristics like height or intellect as such nor one's history as history that accounts for desert. Nor is it any combination of characteristics and history. Rather it is the selfdetermined action. And no combination of one's characteristics and history fully determines what his action is. If one is a person-if that basic requirement of desert holds at all-then one has always the capacity to determine one's actions. If not, then desert is out of the question. But that has already been conceded.

Maybe so. But, indisputably, a person's characteristics and history powerfully affect how he acts; and if the investigation is pursued far enough, it may look as though the autonomous capacity that remains is squeezed into a corner. Why should all the rest be disregarded? Why do some things count as excuses and not others? Anyway, when we finally isolate the autonomous self from the factors that compose the person as he is, it looks like the autonomous self of anyone at all, an undifferentiated locus of decision without any personal characteristics that bind it to the person we have in view. Otherwise it would not be truly autonomous.

Coming at the matter from the other end, one might ask why selfdetermined conduct has the significance it has for desert? The consequences of the conduct may not affect the person himself at all. How does he, being unchanged, incur a susceptibility to some change as his due, presumably because something else (by his action) is changed? That unfamiliar form of the question almost breaks out when a person declares that he is sorry for

21. See generally Kadish, supra note 9. 
what he has done and therefore that he does not deserve to be punished. Why should he be made to feel pain because his conduct sometime in the past was wrong, as he now recognizes? If we believe his declaration-as sometimes we must-and punish nonetheless, desert seems to attach to the conduct and not to the person, while the punishment attaches exclusively to the person, as gratuitous pain. ${ }^{22}$

Perhaps when we speak about self-determined conduct we really mean not a determination by the self but a determination of the self, of which the conduct is evidence: something like, "That being the person he has determined himself to be, then this, which is the due of such a person, is what he deserves." That has a neat aspect, a person's desert attaching uniquely to him because he has determined himself to be that person. But it seems rather remote and abstract, as if desert attached to a self that we never quite encounter and not to the flesh and blood person who is actually punished. One may amplify the argument by a reference to the person's character (of which the conduct is evidence) as the basis of punishment, rather than an abstract self. ${ }^{23}$ But that seems to have the matter backwards from the point of view of desert. On that basis, if a bad character refers to anything other than regular bad conduct (even to a disposition to engage in bad conduct), surely the person is less deserving of punishment when he behaves badly, since he would have had to work harder to behave well than someone who has a good character. The suggestion that there is greater joy in heaven from one sinner saved than from all the angels seems a bit unfair to those who have no impulse to $\sin$.

If the willingness to excuse conduct in certain circumstances but not others betokens an inconsistency in the abstract idea of desert, excuses also indicate a good deal about how attributions of desert are made concretely. We seem generally to start with a model of responsible action defined not by the nature of the act but by reference to the notion of a person, an abstraction loosely associated with an adult human being identified as such by physical characteristics alone. In the absence of special excusing circumstances, that model is presumed to be applicable, and the attribution is taken for granted. Although the nature of the act is not conclusive either way, conduct outside a range of normal behavior may prompt an inquiry to see whether there are circumstances of excuse or mitigation. The "range of normal behavior" refers not only to human behavior in general but also to the particular person, so that if someone behaves "out of character," we look for an explanation. There does not seem to be any general principle that determines definitively what factors count as a sufficient explanation to displace responsibility; often,

22. That attachment seems to be true even though personal identity is continuous over time. What is the connection between this person's conduct in the past and his punishment now, if the conduct left him unchanged? The short response is that the question misunderstands the notion of desert from the start and proceeds from a consequentialist point of view. But the question remains: What then is desert, which makes consequences beside the point?

23. Cf. D. Hume, Enquiries Concerning the Human Understanding and Concerning the Principles of Morals 98-99 (L.A. Selby-Bigge 3d ed. 1975) (posthumous ed. 1777). 
the degree of abnormality of the conduct, inconclusive by itself, seems relevant to the conclusion. In the end, the only way to demonstrate that an attribution of desert or a failure to attribute desert is mistaken is by a comparison with other agreed cases. If that leaves some cases in doubt, it is enough for most. Since we know, without benefit of explanation, that persons sometimes are responsible and sometimes not, the lack of a general explanatory theory does not invalidate our conclusions. ${ }^{24}$ One may add that, despite the importance that we may attach privately to judgments about desert, they commonly have little "official" impact. If we disagree, each of us is able to give effect to his own judgment without disabling others from giving effect to theirs.

The fact that we do make concrete attributions of responsibility and desert in this way, as an ordinary aspect of our experience that seems to flow directly from our recognition of other persons, has led some philosophers to deny that there is any abstract problem. When we speak of a person's desert, they urge, we do not mean to imply anything about the ultimate desert of the person to be the person she is-whatever that might mean. We mean only that this person-as she is now-has done well or ill. We identify her as an actor and express our approval or disapproval of the act, nothing more. In Professor Nozick's apt phrase, desert does not have to go "all the way down."25 If all that a person is had to be deserved in order for her to deserve at all, there could be no person as the subject of desert. The effort to apprehend an autonomous self in isolation from a person's characteristics and life history is misconceived from the start.

Professor Strawson has made a more elaborate argument to the same general effect. There is, he says, no contradiction between the perception of ourselves as autonomous and deserving (the "participant" standpoint) and the perception of ourselves as constituted by characteristics and history nonautonomously acquired (the "objective" standpoint):

[T] he appearance of contradiction arises only if we assume the existence of some metaphysically absolute standpoint from which we can judge between the two standpoints I have been contrasting. But there is no such superior standpoint - or none that we know of; it is the idea of such a standpoint that is the illusion. Once that illusion is abandoned, the appearance of contradiction is dispelled. We can recognize, in our conception of the real, a reasonable relativity to standpoints that we do know and can occupy. Relative to the standpoint which we normally occupy as social beings, prone to moral and personal reactive attitudes, human actions, or some of them, are morally toned and propertied in the diverse ways signified in our rich vocabulary of moral appraisal. Relative to the detached naturalistic standpoint which we can sometimes occupy, they have no properties but those which can be described in the

24. Immediately above, I suggested that responsibility is associated with the idea of a person, whereas here I observe that persons are responsible "sometimes." It seems preferable to accept the ambiguity of ordinary speech, which will, I think, mislead no one here, rather than to wrestle with ways to avoid it.

25. R. Nozick, ANarchy, State, and Utopia 225 (1974). 
vocabularies of naturalistic analysis and explanation (including, of course, psychological analysis and explanation). ${ }^{26}$

That is not an evasion of the problem, Strawson says, because the duality of the human condition in this respect is simply a matter of fact. Sometimes we see one image and sometimes another; but our vision is not defective, nor can we even say what it would be like to bring the two images into single focus at the same time. Our experience of ourselves as persons in the natural world starts from the dual points of view, which are not subject to correction.

Strawson's account may alleviate our perplexity because it appears to separate the abstract problem of desert from questions about individual desert in concrete circumstances. As for the former, as he says, we cannot even describe what we want. As for the latter, we ordinarily know unhesitatingly which of the alternative points of view to adopt. Even to say that we "adopt" a point of view is too much; rather, we simply perceive from one point of view or the other.

The separation between the abstract problem and concrete instances cannot always be maintained as Strawson proposes, however. When an attribution of desert is challenged on the kind of grounds that, if accepted, constitute an excuse, the abstract issue is made concrete by evidence that supports the "objective" standpoint. Not every such explanation will be accepted; the very core of Strawson's argument about dual standpoints is that not every such explanation can be accepted, although in principle one might be offered in every case. If we insist on the attribution, despite the actual or theoretical availability of an explanation from the other standpoint, we have to provide an answer to the protest, "I don't deserve this." Similarly, if we reject an attribution of desert, we have to be able to withstand the challenge, "Why not?" Even if we are not able to say exactly what sort of answer would be satisfactory, the question that troubles us is not one that we decide to ask, and I do not see how we can decide not to ask it. ${ }^{27}$ Strawson seems to dismiss

26. P.F. Strawson, Skepticism and Naturalism: Some Varieties 38 (1985). See Strawson, Freedom and Resentment, 48 Proc. Brit. Acad. 187 (1962), reprinted in P.F. STrawson, FreEdom and RESENTMENT 1-25 (1974).

27. In a recent insightful study of the doctrines of excuse in the criminal law, Michael Moore has argued persuasively that the basis of excuse cannot be simply that a causal explanation has been found for the conduct in question. If that were the basis of excuse, all our conduct would in principle be excusable and individual responsibility would be eliminated altogether. Moore, Causation and the Excuses, 73 Calif. L. Rev. 1091 (1985). On the contrary, he argues, "it is perfectly compatible to think both that persons are autonomous and that everything they do is caused by some set of factors external to their will." Id. at 1132. Like Strawson, Moore points to the indubitable reality that human beings are responsible over much of their lives. He suggests that our imprecise, partial, or occasional moral attitudes that express sympathy and understanding for a wrongdoer who has had an "unfortunate" past are, in the context of our total moral experience, misconceived, except in the specific areas in which an excuse is recognized. Finally, he thinks it is possible to unify the discrete excuses in a theory about the exercise of "practical reasoning capacities." $I d$. at 1148 . Excuses are recognized, he says, when practical reasoning capacities are impaired.

Moore and I are in considerable agreement. We agree entirely about the basic point that a causal explanation cannot ipso facto eliminate responsibility. We agree that our experience of ourselves and others conclusively contradicts any such simple dichotomy. We disagree, however, about what to do next. For it is not only our moral experience that has to be rendered plausible and coherent. Pervasively throughout other areas of our experience a causal explanation does count as sufficient. 
that whole aspect of the matter with the observation that "human actions, or some of them" are fit for moral appraisal.

III

\section{Criminal Responsibility}

Criminal law is the most explicit and formal communal application of what Strawson calls the participant standpoint. When the community declares that someone is guilty of a crime, it affirms his responsibility and gives it consequences. For the most part, as one would expect, the law follows our general understanding. The ordinary assumption, expressed indirectly by the requirement of mens rea, is that a person is responsible for his acts. Although they are not entirely congruent, most of the grounds of excuse in everyday life also constitute defenses against an accusation of crime. ${ }^{28}$

The legal doctrines that define a specific defense of this kind resolve the general issue of responsibility by prescribing a line of separation between the participant and objective standpoints. So long as the doctrines themselves are accepted on their own terms, their application appears to be a matter of fact, which, however difficult or complex, is to be determined like other factual issues. If the doctrines are called in question, the general issue emerges. Unlike challenges to other principles of law, the doctrinal questions about responsibility seem themselves to be questions of fact, albeit of a different order from questions about their application. If we consider whether the defense of insanity or intoxication or duress ought to be modified in some way, the question that apparently needs to be answered is not whether a person in such circumstances ought to be (regarded as) responsible but whether he is responsible, whether we can properly regard him as responsible. Or if, speaking more carefully, we say that the question before us is whether the person ought to be held criminally responsible, the answer to the question seems to depend unequivocally on the question whether he is in fact responsible. ${ }^{29}$

The price of validating our moral experience in the manner that Moore chooses is, at least without further explanation, a deep rupture in the framework of our general experience of the world. (I am doubtful that he can unify our excuses by reference only to practical reasoning capacities. The apparent ground of unification, surely, is that some other, presumably causal, process has taken over and wiped out those capacities.)

Moore focuses principally on responsibility; I suspect that he would find it less easy summarily to dismiss the causal assault if he had discussed desert more explicitly. Yet responsibility and desert, as I believe he agrees, are indissolubly linked. In the end, Moore and I agree that what is at stake, stated most generally, is a fundamental difference between persons and things. The issue between us is how far to (try to) go to unpack that difference and how to go about it.

28. Not all of the grounds of exculpation that the criminal law denominates as "excuses" are excuses in the ordinary sense. See supra note 15. See generally Fletcher, supra note 15; Greenawalt, supra note 15.

29. Occasionally, the two questions appear to be separated not only formally but substantively. The verdict of "guilty but insane" suggests such a separation. See generally McGraw, FarthingCapowich \& Keilitz, The "Guilty But Mentally Ill" Plea and Verdict: Current State of the Knowledge, 30 VILL. L. Rev. 117 (1985); Note, The Guilty But Mentally Ill Verdict and Due Process, 92 YaLe L.J. 475 (1983). If the questions were truly regarded as separate, the appropriate verdict would be "guilty and insane." Similarly, in some discussions of duress and voluntary intoxication, those who would restrict the 
In his famous Durham opinion, Judge Bazelon, writing about the insanity defense, said:

The legal and moral traditions of the western world require that those who, of their own free will and with evil intent (sometimes called mens rea), commit acts which violate the law, shall be criminally responsible for those acts. Our traditions also require that where such acts stem from and are the product of a mental disease or defect as those terms are used herein, moral blame shall not attach, and hence there will not be criminal responsibility. ${ }^{30}$

The Durham test of insanity finally failed because the gradations of mental competence could not be reduced to two mutually exclusive descriptive categories along the lines that the test indicated. Subsequent cases showed that one might conclude that an act was the product of a mental disease or defect and nevertheless conclude that the person was not altogether without responsibility. But so far as the operation of the criminal law is concerned, Judge Bazelon was correct. There is no room for two standpoints. If it is established that the defendant's act is the product of causes beyond his control, criminal responsibility is removed. ${ }^{31}$

The difficulty of this "either-or" framing of the general issue was exposed dramatically in Powell $v$. Texas, ${ }^{32}$ in which the defendant sought to challenge the claim that he was responsible directly, without reference to a specific legal doctrine of excuse. He was charged with being drunk in a public place and defended on the ground that he was a chronic alcoholic. In an opinion for four Justices of the Supreme Court, Justice Marshall upheld the trial court's ruling that chronic alcoholism was not a defense. Distinguishing the earlier Robinson case, ${ }^{33}$ in which the Court had invalidated a conviction for being a narcotics addict, Justice Marshall said:

[T]he entire thrust of Robinson's interpretation of the Cruel and Unusual Punishment Clause is that criminal penalties may be inflicted only if the accused has committed some act, has engaged in some behavior, which society has an interest in preventing, or perhaps in historical common law terms, has committed some actus reus. It thus does not deal with the question of whether certain conduct cannot constitutionally be punished because it is, in some sense, "involuntary" or "occasioned by a compulsion." 34

defense offer arguments that seem to suggest that doing so will have the effect of increasing obedience to the law without any exercise of responsibility by the person in question. A strictly behaviorist analysis of human action allows that approach.

30. Durham v. United States, 214 F.2d 862, 876 (D.C. Cir. 1954) (footnote omitted), overruled, United States v. Brawner, 471 F.2d 969 (D.C. Cir. 1972).

31. In practice, the criminal law hedges its answer to the factual question in much the way that we do in our ordinary, unofficial moral assessments. Not only the defense of "diminished responsibility," which is recognized in some jurisdictions, but also various doctrines of mitigation and gradation of offenses as well as the exercise of discretion in sentencing may allow a considerable measure of shading, which no doubt sometimes reflects uncertainty whether the defendant was responsible at all rather than a clear conclusion that he was "less" or "partially" responsible. Nevertheless, insofar as the defendant is found guilty, the question whether he was responsible for his conduct must have been answered in the affirmative.

32. 392 U.S. 514 (1968).

33. Robinson v. California, 370 U.S. 660 (1962).

34. 392 U.S. at 533. 
In a dissenting opinion joined by three other Justices, Justice Fortas stated his disagreement bluntly: "Criminal penalties may not be inflicted upon a person for being in a condition he is powerless to change." 35 Justice White, who voted to uphold the conviction on other grounds, sided with the dissent on the main issue. ${ }^{36}$ He said, even more plainly than Justice Fortas, that if one cannot be punished for a condition, neither can he be punished for conduct that follows inescapably from the condition; if Justice Marshall's reference to an "actus reus" meant otherwise, he was wrong.

According to the general principles of criminal law, if the result in Powell is acceptable at all, it is because the evidence does not entirely convince us that the defendant "couldn't help it." Justice Marshall alludes to such doubt, without attempting to explain or justify it, in the parenthetical phrase, "in some sense." In effect, he straddles the question whether Powell's defense is inadequate factually or legally. ${ }^{37}$ But unless Justice Marshall would say that, constitutionally at least, responsibility is unnecessary for criminal responsibility, or guilt, if the defense is not inadequate factually, then it is incomprehensible how it can be inadequate legally. Justice Black wrote a separate opinion, in which he skirted the issue of responsibility in a different way. He defended Powell's conviction on utilitarian grounds, and added, not incidentally, that the jailing of alcoholics might be regarded as a form of therapy (!) and that in any case there seemed to be no practical alternative. ${ }^{38}$

The courts have reached results similar to those in Powell in a number of other cases in which the defendant asserted without benefit of an established defense that he was powerless to avoid committing the criminal act. ${ }^{39}$ It is evident that the judges are aware of the abstract issue at stake and troubled by the prospect that the foundations of the criminal law might be undermined by the relentless advance of a method of inquiry-Strawson's objective standpoint-that dismisses the explanatory value of individual free will and responsibility from the start. The issue is present, albeit less vividly, in all the cases in which the defendant relies on a defense that constitutes an excuse from responsibility. In all of them, one may ask on what basis, consistently with other cases, the law adopts one standpoint or the other. If we care to stalk it, the issue lurks in every case whatsoever. ${ }^{40}$ Its ubiquity emerges briefly and dramatically into the open when the law assesses criminal responsibility according to circumstances that are unmistakably beyond the actor's control.

35. Id. at 567 (Fortas, J., dissenting).

36. Id. at 548 (White, J., concurring).

37. Elsewhere in his opinion, Justice Marshall gives a general basis for doubting the conclusion that Powell's act was not voluntary, but he does not make clear whether the doubt is factual or legal. Id. at 521-26.

38. Id. at 537-40 (Black, J., concurring).

39. E.g., United States v. Davis, 772 F.2d 1339 (7th Cir. 1985) (compulsive gambling); United States v. Gould, 741 F.2d 45 (4th Cir. 1984) (same); United States v. Torniero, 735 F.2d 725 (2d Cir. 1984) (same), cert. denied, 469 U.S. 1110 (1985); United States v. Lyons, 731 F.2d 243 (5th Cir.) (en banc) (narcotics addiction), cert. denied, 469 U.S. 930 (1984); United States v. Moore, 486 F.2d 1139 (D.C. Cir.) (same), cert. denied, 414 U.S. 980 (1973).

40. See generally Kelman, Interpretive Construction in the Substantive Criminal Law, 33 Stan. L. Rev. $591(1981)$. 
1. Felony Murder (and Negligent Homicide and Attempts). The felony murder doctrine has a long history in English and American common law and is retained in most recent codifications. ${ }^{41}$ It provides, with qualifications that need not be considered here, that if a person is killed or dies in consequence of the commission of a felony, the felon is criminally liable not only for the felony but also for the death, which is treated as murder ${ }^{42}$ According to the traditional doctrine, the death constitutes murder no less even though the felon took steps to avoid harm to anyone and was altogether unaware of (and incapable of avoiding) the danger.

The short way to explain this peculiar doctrine is similar to H.L.A. Hart's response to what he called the "definitional stop" in discussions about punishment. ${ }^{43}$ If all that troubles us is that the death is called "murder," call it something else to distinguish it from an intentional killing; there is no reason to make so much of a mere lack of linguistic invention. But even if the doctrine were recast as a heightened penalty for the felony itself if someone is killed, the crucial problem of fortuity remains. Why ought we punish for an accident? The troublesome feature about felony murder is not just that the death increases the felon's punishment but that the death is attributed to him at all and qualifies his conduct differently from that of other felons committing the same act.

The question may be asked from any perspective. ${ }^{44}$ From the point of view of retributivists, why ought the felon be punished for a consequence that he did not intend and was not reasonably foreseeable-for what, speaking plainly, he did not do. ${ }^{45}$ Utilitarians point out that one can scarcely be dissuaded or deterred from doing what one has no intention or expectation of doing in the first place. Other utilitarian justifications have been suggested; but they fare no better. The argument that an occasional conviction of murder will deter commission of the underlying felony is met by the response that we could do as much, more efficiently, by convicting every tenth felon of

41. The doctrine was abolished in England in 1957, Homicide Act of 1957,5 \& 6 Eliz. 2, ch. 11 , $\S 1$, and has been abolished in a few states. The current state of American law is reviewed in People v. Aaron, 409 Mich. 672, 299 N.W.2d 304 (1980), in which the Supreme Court of Michigan abrogated the doctrine judicially. See generally Crump \& Crump, In Defense of the Felony Murder Doctrine, 8 Harv. J. L. \& Pub. Pol'y 359 (1985).

42. The case is more complicated but the principle is the same if more than one person engages in the commission of the felony. If the death is not attributable to one felon in particular (for example, the victim of the felony dies of a heart attack later), all the felons are liable alike. If the death is accidental but caused by the action of one felon, accessorial liability makes the act of one the act of all and, once again, all are liable. See, e.g., People v. Stamp, 2 Cal. App. 3d 203, 82 Cal. Rptr. 598 (1969), cert. denied, 400 U.S. 819 (1970) (heart attack); State v. Best, 44 Wyo. 383, 388-89, 12 P.2d 1110,1111 (1932) (accidental killing by one felon).

43. H.L.A. Hart, Prolegomenon to the Principles of Punishment, in Punishment and Responsibility $1-5$ (1968).

44. For an extensive discussion of supposed retributive and utilitarian justifications of resultbased punishments generally, see Schulhofer, supra note 8.

45. In Enmund v. Florida, 458 U.S. 782 (1982) (5-4 decision), rejecting capital punishment for felony murder, the Supreme Court observed: "Putting Enmund to death to avenge two killings that he did not commit and had no intention of committing or causing does not measurably contribute to the retributive end of ensuring that the criminal gets his just deserts." $I d$. at 801 . 
murder (or sentencing him equivalently) whether or not anyone had died. ${ }^{46}$ The argument that the felon is at least put out of the way for a time does not explain why this particular felon is put out of the way for a longer time than others who commit the same felony.

There are responses. Retributionists point to the commission of the felony, itself a serious intentional wrong. Utilitarians also point to the felony and its dangerousness, as evidenced by the actual result. But if it is the felony that attracts the punishment, for retributive or utilitarian reasons, why is it meted out some times and not others? The last stand of retributivists and utilitarians alike is an effort to eliminate the element of fortuity. Given the limitations of our capacity to observe and measure intention and dangerousness, it is reasonable for us to qualify the act itself by its consequences. ${ }^{47}$ The death, then, is not the basis for greater punishment; rather it is good enough evidence for the true basis, which is the especially wrongful and dangerous conduct of the actor. That argument, however, is an attempt to swallow whole what is indigestible in small bites. Sometimes, it is true, the felon's claim that the death was an accident may be suspect or it may be traceable to the special dangerousness of his act.48 But the felony murder doctrine is not cast in terms of those explanations, and it extends much further than they would allow.

The most interesting feature of the felony murder doctrine is its resilience. In two celebrated series of cases, the California courts and the Pennsylvania courts displayed how difficult it is to eliminate the doctrine even though its irrationality from the point of view of either retribution or utility is fully understood. ${ }^{49}$ Most remarkable in this respect is the Model Penal Code's effort to have it both ways. The Code's provisions are the product of careful academic and professional discussion unpressured by the urgencies of an actual case. Having rejected the felony murder doctrine on the straightforward ground that "the criminal law does not predicate liability simply on conduct causing the death of another" 50 and "there is no basis in experience for thinking that homicides which the evidence makes accidental occur with disproportionate frequency in connection with specified felonies," 51 the Code restores the doctrine as a presumption that a person who commits any

46. See O.W. Holmes, The Common Law 48 (1963).

47. In some cases, in which the felon does not challenge his causal responsibility but only his intention, the felony murder doctrine may just lessen the prosecutor's burden of proof on a particularly difficult issue of fact. Even so, one may ask why the stringent requirements of proof are relaxed in this situation.

48. See Schulhofer, supra note 8 , at $1588-99$, for a careful discussion of the dangerousness argument.

49. The California cases are reviewed in Taylor v. Superior Court, 3 Cal. 3d 578, 477 P.2d 131, 91 Cal. Rptr. 275 (1970). For a more recent discussion of the California cases see People v. Dillon, 34 Cal. 3d 441, 668 P.2d 697, 194 Cal. Rptr. 390 (1983). For Pennsylvania, see Commonwealth $e x$ rel. Smith v. Myers, 438 Pa. 218, 261 A.2d 550 (1970).

50. Model Penal Code $\S 210.2$ commentary at 36 (1980).

51. Id. at 38 . 
of six designated felonies had the requisite state of mind for murder. ${ }^{52}$ With disarming frankness, the commentary to this provision acknowledges that the results are likely to be about the same either way; what is important, it says, is that a conviction on the new basis "rests solidly on principle."53 What principle?54

The puzzle of felony murder is duplicated at another level in cases of negligent homicide and what is called misdemeanor manslaughter. Once again, the actor is at fault and, but for his fault, the victim would not have died. The ordinary basis of responsibility, however, is missing; the death was neither intended nor so likely that it should be regarded as part of the act that was intended. Even so, the actor is held criminally liable not just for his negligence (or misdemeanor) but for the death, and sentenced accordingly. Another person, whose conduct is the same without resulting in a death, is punished much less or not at all. ${ }^{55}$ The most common explanation for treating the two cases differently is that otherwise either the negligent conduct will go unpunished, because a jury will not convict if the penalty is severe, or the homicide will be punished too lightly. That, however, only deflects the puzzle from the law to the attitudes of the jurors or the public generally. Why, one wants to know, would jurors react that way? Why does the case that is characterized as homicide call for more severe punishment?56

The relevant fortuities are not only those of the surrounding circumstances; they include the unapparent and, from the point of view of the defendant, fortuitous condition of the victim himself. The well-known rule is that "you take the victim as you find him." 57 In one often cited case, a person who committed a minor assault was found guilty of manslaughter, because the person he struck was, unknown to the defendant, a hemophiliac and died from a small injury. ${ }^{58}$ Almost certainly in such a case, one would say that the

52. Model Penal Code $\S 210.2(b)$ (1980). The six felonies are robbery, rape or deviate sexual intercourse by force or threat of force, arson, burglary, kidnapping, and felonious escape.

53. Model Penal Code $\$ 210.2$ commentary at 39 (1980).

54. The attraction of the felony murder doctrine for the Anglo-American (more recently the American) legal mind does not seem to be duplicated elsewhere. The commentary to the Model Penal Code states that "felony murder is unknown as such in continental Europe." Model Penal CODE $\$ 210.2$ commentary at 40 (1980).

55. There is not a fixed rule that separates conduct from its consequences. If the consequences are substantial, they may contaminate a description of the conduct so that it does not appear to be the same as conduct that has different consequences. If Smith and Jones both drive through a red light and someone is killed as a consequence of Jones' act, we may say that Smith "drove carelessly" and that Jones "killed a pedestrian."

56. The argument about jury "nullification" is discussed at length and with great precision with respect to result-based crime generally in Schulhofer, supra note 8, at 1522-57. Schulhofer concludes that in only a small number of rather special cases the argument is "not demonstrably fallacious" but remains speculative even in them. Id. at 1557. See Crump \& Crump, supra note 41, at 363-69. They argue that since the public perceives a crime from which death results accidentally as more serious than the same crime not attended by a death, various social purposes are served by treating the crime as qualitatively different.

57. E.g., W. LaFave \& A. Scott, Criminal Law 261 (1972). Perhaps accidentally, the rule makes the fortuity sound like something that the actor does.

58. State v. Frazier, 339 Mo. 966, 98 S.W.2d 707 (1936). 
victim died of hemophilia, not that the actor had killed him; the law opts for the latter. ${ }^{59}$

Fortuity plays a role also in the law of criminal attempt. Some conduct punishable as an attempt falls short of the conduct that constitutes the completed crime. In such cases, an explanation for punishing the attempt less severely may perhaps be available from the retributive or the utilitarian perspective. ${ }^{60}$ Explanation is ordinarily lacking if the conduct is complete and would constitute the crime but for a circumstance unknown to the actor. ${ }^{61}$ The actor simply gets the benefit of the accident that makes his attempt not succeed. ${ }^{62}$ As in the case of negligent homicide, one may deflect the puzzle from the law onto the jury; but the puzzle remains.

\section{Self-Defense against an "Innocent" Aggressor. Straightforward cases of self-} defense, in which a person kills someone who would otherwise have killed him, are explicable on retributive or utilitarian grounds. One who is unjustifiably threatened with death (or serious injury) does no wrong if he avoids the threat, even at the (unavoidable) cost of the life of whomever threatens him; the latter can avoid the harm to himself by ending his own wrongful conduct before it is too late. ${ }^{63}$ Nor does any consideration of the general good dictate that the intended victim of an assault spare his assailant's life at the cost of his own. ${ }^{64}$ The law satisfies also a general sense of appropriateness-what we like to call "poetic justice"-since the person at fault has borne the injury he had intended to inflict on someone else. We may acknowledge that aspect of the situation by describing his death as "really" self-inflicted, although, of course, it really is not.

59. In this, as in other similar situations, whether or not the act of the defendant is regarded as the cause of the death would ordinarily depend a good deal on one's assessment of the defendant's blameworthiness. See supra p. 56. The jury, of course, need not find the defendant guilty of homicide. It is instructed separately about each of the elements of the crime, including causation. Probably, separation of the issues in that way makes it easier to reach the ultimate conclusion of responsibility.

60. Among the possible explanations are (i) that the defendant might have desisted at the last minute, (ii) that the defendant's intention may not be certain until it is fully executed, and (iii) that the criminal law ought not be concerned with bad intention as such, which an uncompleted crime too much resembles. Usually such arguments are made to support postponement of liability for an attempt until the crime is all but complete and will be completed unless prevented. They may also serve, albeit rather weakly, to explain why punishment is less for the attempt than for the completed crime. The explanation will be more or less convincing according to how near to the completed crime the attempt comes.

61. The overworked problem of "impossibility" arises in some cases of this kind. For one effort to sort out the badly entangled strands of the problem, see L. WEINREB, Criminal LAW 724-30 (4th ed. 1986).

62. The intended victim also gets the benefit of the accident, but there is no reason why the actor ought to be treated alike in that respect. He intended that the crime occur, and the victim, so to speak, intended that it not occur.

63. The doctrine of "withdrawal" allows a person who has effectively ended his own assault on another person to defend himself if the latter unnecessarily continues to assail him. E.g., United States v. Grover, 485 F.2d 1039 (D.C. Cir. 1973).

64. That is true at least if we know nothing more about the parties and the event than who assaulted whom. The circumstances and the issues that may be raised are a great deal more complex than I indicate here. As uncomplicated statements, these generalizations are, I think, acceptable. 
Most cases in which the need to act in self-defense is only apparent fit the same pattern without too much trimming. The appearance of a need to use deadly force typically arises from an actual assault; the difference between appearance and reality is not that what looked like an assault was not one in fact but that the assailant was not threatening as great a harm as it appeared. Even though there has been an unnecessary death, the retributive and utilitarian considerations that apply in a case of actual self-defense apply here as well. There is no retributive basis for punishment of a person who has acted, according to the apparent circumstances, as the law authorizes him to act; from a moral point of view, his conduct is not distinguishable from that of someone who acts in actual self-defense. The calculation of utility may be more complex. It is possible that on balance lives would be saved if persons were required to confirm absolutely the need to use deadly force before they used it. But we have no access to evidence that would support such a conjecture; and without more evidence, it seems unlikely. ${ }^{65}$ As between the conduct of the victim that creates the appearance of a need to use deadly force and the conduct of the actor who uses it, there is not much to choose one way or the other as the cause of the homicide. If there is not so strong a sense of poetic justice, one may still regard the victim's death as, in some sense, selfinflicted. 66

The cases of defensive homicide that most trouble the theories of criminal law are those in which the conduct of the person who is killed, insofar as it constitutes a threat, is not regarded as self-determined, because he is unaware and has no reason to be aware that his conduct endangers someone else or because he is acting to save his own life in circumstances for which he has no responsibility. Although actual cases are few, the situation may not be as unlikely as one supposes. It encompasses not only the law teacher's corny case of the birdwatcher threatened by a near-sighted hunter, ${ }^{67}$ but any situation in which there is a means of escape for only one person from a deadly peril that threatens two: a supply of food that will sustain one but not two stranded hikers; a life raft that will support one but not two persons overboard, and so forth. 68

65. The law requires that the appearance of necessity be enough to convince a reasonable person. Someone who unreasonably believes that he is threatened by another person and responds with deadly force is guilty of homicide.

66. With some imagination, one can posit a case in which the conduct that creates an apparent need for someone to act in self-defense is entirely innocent; the person has no reason to suppose that his conduct appears to someone else to threaten his life. Such a case of an "innocent apparent aggressor" would be assimilated to the case of an innocent actual aggressor, discussed below, especially the faute de mieux case in which there is no reason to label one party or the other the aggressor at all, except that the (innocent) conduct of one threatens the life of the other (who is also innocent). In such a case, there is no question of poetic justice. One may want to add that there is no question of justice of any kind.

67. See L. WEINREB, supra note 61 , at 226.

68. The category might be extended to cases involving more than two persons, of whom fewer than all can be saved. The famous case of United States v. Holmes, 26 F. Cas. 360 (C.C.E.D.Pa. 1842) (No. 15,383) is an example. Such cases are usually thought to raise special questions of process-drawing lots and so forth-that, interestingly, are not much discussed even hypothetically if only two persons are involved and the issue is simply "him or me." 
I am aware of no rule of law that resolves such cases clearly. The doctrine of self-defense applies to defensive acts against a person who unjustifiably threatens the actor. The doctrine of necessity refers to avoidance of a harm greater than that caused by one's conduct, which perhaps applies when more lives are saved than taken but certainly does not apply to a choice of one's own life over that of another person. ${ }^{69}$ Neither the retributive nor the utilitarian argument dictates an outcome. The situation is described abstractly without reference to fault of either person; and, even if we admire an attitude of self-sacrifice, we suppose that we cannot and in any event ought not in general deter persons from competing for self-preservation. ${ }^{70}$

One might expect, therefore, that the criminal law is simply silent. Perhaps in actual practice it usually is silent; such cases when they arise are bound to be extraordinary and likely to call for resort to the informal processes of the law, like an exercise of prosecutorial discretion. The general doctrinal position of the law is, I think, more complicated. So far as one can discern any rules, the law is that a person can act to preserve himself, but only without aggression against another. That sounds correct; it is consistent with the doctrine of self-defense, which excuses the victim of aggression who responds with defensive force. What counts as aggression when two persons are threatened by the same peril and only one can escape is, however, far from clear.

The survival of each person being a barrier to the survival of the other, one might regard the legal principle allowing the use of deadly force in necessary self-defense as available to both. I am fairly confident that the law would resolve the problem by concluding that if either person acts in a way that would be criminal in ordinary circumstances, his act will constitute him the aggressor and determine the issue of self-defense and, ultimately, homicide. While both are in the water, each may swim as fast as he can; but if the slower swimmer tries to impede the other by any kind of physical assault he is an "aggressor," against whom the other person can use whatever force is necessary to defend himself. The raft supporting only one person, whoever reaches it first acts defensively against the "aggression" of another person who tries to board it. The result is clearer if one supposes that the person on the raft was on it from the moment the ship went down and that the other person swims up some hours later. ${ }^{71}$ The same results in principle would, I

69. E.g., Model Penal Code $\$ 3.02$ (1985), which provides in part: “(1) Conduct which the actor believes to be necessary to avoid a harm or evil to himself or to another is justifiable, provided that: (a) the harm or evil sought to be avoided by such conduct is greater than that sought to be prevented by the law defining the offense charged ...."

70. One might want to say that utilitarianism dictates an outcome in principle and that only a contingent factor, our inability or failure to gather enough information, leaves the outcome in doubt. Any such principle would most likely be so abstract and the facts required for its application so many and so inaccessible that it would not be applicable at all as a practical matter. For reasons suggested at the beginning of this article and discussed more fully below, I believe that the excuse "not enough facts" is an evasion of the deficiency of utilitarianism generally.

71. Or suppose that while the ship is going down one person discovers that his life vest is defective and grabs the vest of another person just as the latter is about to put it on. Even though the 
think, be reached in other kinds of situation involving a joint peril. If two hikers had enough food for only one to survive, the person carrying the food would prevail, even though their division of responsibilities had been made without any view to their current situation. ${ }^{72}$ In the birdwatcher/hunter situation, where one person's act unknown to him threatens the life of another person, the result would also turn, I think, on a small fault. If either of the two were a trespasser, for example, bizarre as it sounds, I believe that that would be decisive. If neither were at fault at all, the one whose act threatened to kill would, faute de mieux, be labeled the aggressor so that the other would be allowed to use deadly force in self-defense.

If my reading of the law in such cases is correct, the outcomes bear considerable resemblance to felony murder. In both kinds of situation, the act to which liability for homicide attaches seems unable to bear so much weight, because the death was unintended and unforeseen or because the intention to kill was incidental to the imposed necessity to save oneself. The felon chooses "freely" to commit the felony, whereas the person in the water is "forced" to choose. On that basis, most people would probably regard the latter as less culpable. So far as the death is concerned, however, the felon did not choose to kill anyone at all, whereas the person in the water, forced or not, did choose to save his life by taking the life of another innocent person. The comparative moral judgment is not so clear.

Various analyses of the cases involving a mutual peril have been suggested. The critical element, however, which they do not address, is that the fault that makes a person an aggressor is swamped by the necessity that causes him to act as he does. But for the necessity, he would not have committed the act. The necessity unquestionably excuses the act itself. Without such an act, the person would be allowed to save himself, even if a consequence of doing so were the death of another person. Yet when the act and the death are connected, the fault is reinstated not with respect to the act but with respect to the homicide. The short way through that labyrinth is usually simply that a person is allowed to save his own life but not by taking

distribution of the defective vest was entirely a matter of chance, the invasion of the latter person's brief possession would make the former person the aggressor.

72. A friend who works in the field of criminal law has expressed some doubt. Suppose that Smith and Jones are hiking. As they agreed when they planned the trip, Smith bought and is carrying the food. Jones paid for the camping permit and is carrying the tent. They become lost, have small hope of being discovered or finding their way out for a long time (an avalanche), and there is food in Smith's pack sufficient for the survival of only one. If Smith, using only the force necessary to defend himself while fending off Jones' attempt to take the food, kills Jones and eats the food, is he (rescued the next day in time for both to have been saved, the usual surprise) guilty of homicide? Surely not. If Jones overcomes Smith's resistance and takes the food, is he guilty of homicide if Smith dies and it is proved that he would have survived if he had had the food? I think so. The situations are, at any rate, perceptibly distinct. Perhaps it is Jones' aggressive act, rather than Smith's possession of the food that makes the difference. If so, what about Smith's calmly sitting down to (his) dinner, while Jones sits on his haunches and watches? If the person carrying the food is not the owner, or the sole owner, the situation is more complicated; so is the law of theft. To simplify the problem (by complicating the facts) suppose that Smith and Jones, who are strangers to one another, are sole survivors of an airplane crash on a mountain. Before the crash, Smith stuffed the food on his luncheon tray into his pockets. 
the life of someone else. Stated that simply, however, the argument proves too much or too little; it is only the characterization of an act as "aggression" that allows us to distinguish self-defense from what is equally life-saving but not self-defense. That characterization turns on a "fault" that, in the circumstances, would not be a fault at all but for the death.

3. Fault of the Victim. The doctrine of provocation, by which an intentional killing that would otherwise be murder is "reduced" to voluntary manslaughter, is usually understood as a concession to human frailty: in extreme circumstances, a person may be so provoked that even homicide is, to some degree, comprehensible. Having been provoked, he is less at fault (according to the retributivist) or he was less subject to the deterrent effect of the law (according to the utilitarian). Although the doctrine is not always expressly so limited, it is clear that what is principally included are provocations by the victim of the homicide. Cases are extremely rare in which the source of the provocation is someone or something else. ${ }^{73}$ The Model Penal Code broadens the circumstances of mitigation to include any "extreme mental or emotional disturbance for which there is reasonable explanation or excuse."74 Even under that extended formulation, it is doubtful that provocation by a third person will often be accepted, at least if the victim and the third person are not related. Paradigmatically and almost always in practice, therefore, the doctrine of provocation gives some recognition to the victim's own fault as a factor mitigating the liability of the actor. One might just say that the victim "asked for it" and let it go at that. But that is again a reference to poetic justice and has nothing to do with the purposes of criminal law. From both the retributive and utilitarian perspectives, the source of the provocation by itself should make no difference.

The doctrine-now under attack-that one who goes to the aid of someone engaged in combat with another person acts "at his peril" invites a similar interpretation. ${ }^{75}$ From the retributive point of view, a reasonable mistake about whom to aid ought not affect the qualification of one's act. Someone who mistakenly but reasonably identifies the wrong person as the victim of the combat and goes to his aid is not at fault; his mistake may be occasion for regret, but strictly morally, his conduct is as commendable as if he had made no mistake. Utilitarian arguments fare no better. The peril of being mistaken may make people less willing to meddle without adequate information; or it may simply make them less willing to intervene at all, even when there is no mistake and intervention would be desirable. It is impossible to say which; but a requirement that a mistake be reasonable rather than that there be no mistake seems likely to come nearer to our general objectives.

73. For an example, in which the court concluded, as I suggest here, that the doctrine of provocation does not apply unless the victim is the source of the provocation, see People v. Spurlin, 156 Cal. App. 3d 119, 202 Cal. Rptr. 663 (4th Dist. 1984).

74. Model Penal Code $\S 210.3(1)$ (b) (1985).

75. See W. LAFAve \& A. ScotT, supra note 57, at 397-99. 
The peril rule, however, satisfies in a peculiar way an aspect of responsibility or desert that the excuse of reasonable mistake does not. If the intervenor unavoidably uses deadly force against an aggressor to save the life of the latter's intended victim, the aggressor's death can without much strain be described as caused by his own self-determined conduct and attributed to his own fault, as in a case of self-defense. If the intervenor goes to the aid of the aggressor and kills the intended victim, an innocent person is dead, and the aggressor's fault and the death are clearly separate. Unless the aggressor invited the intervention, it is too much to hold him responsible for the intervenor's self-determined mistaken act, however reasonable it may have been. The doctrine that an intervenor acts at his peril avoids an outcome that would force us to treat the death as an accident, despite the entire innocence of the victim, the fault of the aggressor, and the error of the intervenor. By allowing us to fix responsibility on a human actor, it brings the situation closer in one important respect to cases of self-defense, even though apparent necessity is recognized in the latter and not the former.

The doctrines discussed on the preceding pages are not all of a piece. There are many differences among them; according to the usual distinctions of the criminal law, they do not readily compose a coherent category. Some, like felony murder and negligent homicide, attempts, and provocation, have familiar and recurrent applications in the mine run of criminal cases. Occasions for application of others, notably the innocent aggressor, are extremely rare. Nor are the doctrines separately or collectively an invariable or inextricable part of the criminal law. All are the subject of criticism and, to one degree or another, have been questioned, limited, or rejected in some jurisdictions. Nevertheless, they are illustrative of a tendency of the law sometimes to give the consequences of conduct significance for criminal responsibility that they would not be given by reflective normative judgment. As a result, the defendant's punishment, in comparison with that of other defendants, may be greater or less, without justification according to either retributive or utilitarian theories of punishment. For the most part, these types of cases are treated as idiosyncratic and unrelated departures from a largely consistent theoretical ideal. From a sufficient distance, however, they display a common pattern. The tendency that they illustrate appears most strongly when (1) there is a very substantial harm, (2) the harm would not have occurred but for the specific, identifiable fault of a specific person, ${ }^{76}$ and (3) no other person is manifestly so much in control of the event that his conduct is regarded as the cause of the harm. ${ }^{77}$ The doctrines are,

76. The third-party defense case seems to fit this description least well because the fault in question is not a moral failing in any respect but only a (reasonable) mistake; that case is also, however, the one in which the actor's causal responsibility for the death is most unequivocal.

77. See, for example, cases in which a policeman kills an innocent person while trying to prevent commission of a felony. His involvement is regarded as highly relevant to the felon's liability, even though it is a consequence of the felon's conduct. Compare Commonwealth ex rel. Smith v. Myers, 438 Pa. 218, 26l A.2d 550 (1970) (liability rejected) with People v. Hickman, 12 Ill. App. 3d 412, 297 N.E.2d 582 (1973), aff'd, 59 Ill.2d 89, 319 N.E.2d 511 (1974), cert. denied, 421 U.S. 913 (1975) 
furthermore, sufficiently resistant to change to suggest that, despite their factual variety, they may have a common source.

\section{IV}

\section{The Normative Ontological Perspective}

The criminal law's occasional, discordant emphasis on normatively separable faults, which is described in section three, is generally regarded as a mistake. The attraction of responsibility for a harm to a fault to which the harm is related only by "but-for" causation is understood to be a response, "human" but theoretically misconceived, to our grief and anger at the harm itself-an irrational "striking out" at someone without whose wrongful conduct the harm would not have occurred. When we are confronted by the death of an innocent person in the course of a felony, it is not surprising that the accurate statement, "If you hadn't committed the felony, she would still be alive," should become "You killed her," and finally, "You murderer!" Whatever fortuities were also necessary to the result are swept from view by the aspect of the occurrence for which responsibility is clear. Similarly, the survivor of a joint peril whose deliberate act was the cause alike of his survival and the non-survival of someone else bears the burden of the death. We may understand his situation and mitigate the crime. Just the same, he had no greater right to life than the person he "killed." The nonsurvivor was in the same peril, and, as between the two. ... The doctrines about provocation and defense of a third person likewise are presumed to reflect a strongly felt "intuitive" response to the situation, rather than a reflective judgment.

Although the doctrines that support such results contradict our usual, well-settled understanding of the conditions in which responsibility and susceptibility to punishment attach, they are not, or not simply, a mistake. They reflect the deep ontological assumption that human experience is contained within, or composes, a normative order. That assumption appears on the surface in the cases that trouble us, because it is extended beyond its conventional limits; but it is just as essential to our resolution of untroubling cases and, except as a matter of convention, no better validated in the latter than in the former. Far from challenging the assumption, its untoward extension can be perceived as a deep, inexplicit reinforcement of it. In none of the cases is it exact to say that the assumption is correct or not correct except, once again, conventionally. It is a structural element of human experience as we know it.

(liability approved). Cases in which a felon is held vicariously liable for the act of a co-felon do not contradict the relevance of this factor. The former's liability is based on principles of vicarious liability that are independent of the considerations involved here. See generally Kadish, Complicity. Cause and Blame: A Study in the Interpretation of Doctrine, 73 Cal.1F. L. Rev. 323 (1985). The provocation cases are perhaps contradictory; it depends on how strongly one construes "manifestly . . . in control." (Provocation, of course, is taken to induce a loss of control by the actor. But that is selfcontrol, a somewhat different, although not unrelated, matter.) If one so regards those cases, this factor has to be regarded as relevant often but not always. 
The heart of the matter is the problem about desert. It is not simply that we sometimes have a difficult time deciding whether to hold a person responsible or not. Nor is it, fully stated, that we know persons are (sometimes) free and responsible and we cannot account for their freedom consistently with their place in a determinate natural order. ${ }^{78}$ Rather the problem concerns the conditions of freedom itself. Freedom without desert is a descriptive concept without normative significance. It is like the freedom of a plant after the trellis collapses or of a dog that gets out the gate. Both are free in a way they had not been before; but desert does not attach because we do not regard them as responsible for how the freedom is played out. ${ }^{79}$ That by itself is not a difficulty; we need only affirm, as we do, that the exercise of normatively significant freedom gives rise to desert. Desert, however, seems to require that a person's acts be both free and determinate. Unless they are free, the person cannot be said to be morally responsible, and desert is out of the question. By the same token, a person is not responsible for circumstances beyond his control-circumstances, that is, that are not the product of his freedom. But then, unless the conditions in which a person acts are fully determined according to his desert, they are arbitrary from a moral point of view; furthermore, unless such deserved conditions fully determine his action, an attribution of desert according to how he exercises his freedom also is morally arbitrary. If freedom requires desert, it seems to require that the exercise of freedom itself be determinate. But if desert requires freedom, that is a contradiction. Desert cannot depend on freedom and at the same time freedom depend on desert.

The contradiction is avoided if either dependence is rejected. The usual method of avoidance nowadays is to reject the dependence of freedom on desert. So, Nozick insists, desert does not have to go "all the way down." Strawson's resolution of the problem comes out in the same place for essentially the same reasons, as must any account that accepts the fundamental opposition between freedom and cause and the limitation of responsibility and desert to freedom. In the end, freedom is made independent of desert because desert is not-cannot be made-independent of freedom.

This account of freedom reflects how we ordinarily think about these matters. We do, as Nozick and Strawson say, affirm that a person deserves well or ill without insisting that he have deserved all the factors that might explain his conduct. We believe that a person may be free and responsible even though he does not deserve to be and to have all that he is and has. There is no basis for that account, however, except the very contradiction that

78. Strawson's statement of the problem as consisting of two incompatible standpoints frames it this way.

79. Compare the Epicurean doctrine that explained free will by a "swerve" or absolutely undetermined motion of atoms that are otherwise subject to strict causal laws. See A. Long, Hellenistic Philosophy 56-61 (1974). Such a doctrine might contribute to a condition of ataraxia, or quietude, by eliminating indeterminacy. As an account of human freedom and responsibility, it is hopeless. The Greek word tyche referred to both chance and necessity. 
it is offered to resolve: the fact that we do deserve even though many, and in principle all, of the constituents of our freedom are themselves ultimately determinate causally and (therefore) not according to desert. So far as the problem of desert itself is concerned, convention aside, it is just as convincing to affirm the opposite: since we do deserve and desert is not morally arbitrary, it does not depend on freedom. The determinate factors that compose our freedom, although beyond our control, are themselves deserved. Desert does go all the way down or, more comfortably perhaps, it is as if desert goes all the way down. Although the two solutions are precisely opposed, neither one has an advantage over the other; according to both, albeit from different perspectives, desert is morally arbitrary.

The current preference for the former solution reflects our concentration on desert (or justice) as a problem of ethics. The reality of freedom, arbitrary or not, is assumed; and desert is tied to it. Earlier, the problem was stated in ontological terms. The deservedness of our natural condition, determinate or not, was assumed; and freedom was tied to it. The idea of a normative order immanent in nature is built as deeply into the classical Greek conception of what there is as the idea of causation is built into ours. ${ }^{80}$ More familiarly, normative natural order is the core of the Christian conception of divine Providence (or the Eternal Law, in the system of Thomas Aquinas) and, particularly, the conception of original sin. ${ }^{81}$ One way or another, it is part of any philosophy that bases the meaning and significance of human existence on something other than what is imparted by human beings themselves. Considered abstractly, it seems to be not much more than a matter of philosophic currency and intellectual preference as well, of course, as deep convention whether one regards desert as arising out of conditions that are morally arbitrary or regards the natural order as morally significant. Both are indemonstrable, unanalyzable assumptions that rest finally on our recognition of human beings as morally responsible: persons rather than things.

The cases described in section three are troubling because criminal liability arises from a circumstance that ordinarily would be regarded as unrelated to the defendant's exercise of freedom. In cases of felony murder and fortuitous homicide generally, the felon's act is fully described-“used up"-without reference to the death, which was not forewarned in the circumstances at the time of the act. So far as his conduct is concerned, the death makes no difference. Therefore, it is argued, the death does not affect the felon's desert and ought not affect his punishment. As an event in the natural order, the death is not a fortuity. It is not a random occurrence that "just happened." On the contrary, the events leading to the death are determinate; and, in particular, the death would not have occurred but for the commission of the felony. That, however, gives no comfort so far as the

80. Among the concepts that gave expression to the idea are moira, kosmos, and physis, which we translate inadequately as, respectively, fate, cosmos or order, and nature.

81. The reference to Divine Providence explicitly removed the problem beyond the range of human understanding. 
felon's liability is concerned. For, if the death is regarded in that wayStrawson's objective standpoint-freedom is excluded from consideration, and there is no question of responsibility or desert at all.

Even if, by a willing suspension of disbelief, we were to adopt the ontological approach to the problem of desert, we seem no nearer a solution. The idea of normative natural order does not mean that a person can be said to deserve anything at all; it does not mean that, willy-nilly, he deserves to be punished because someone has died in Casablanca. ${ }^{82}$ In this case, the death is closer to home; the felony, which itself is an exercise in freedom, is discernibly causally related to the death. Even so, normative natural order refers to the dispensations of nature. It requires that individual desert be determinate and, therefore, not subject to determination by human dispensation. The judgment that the felon is guilty of murder and deserves to be punished as a murderer is pronounced not by nature but by us. Of course, we may say that the felon is a murderer: "You killed her. You murderer!" But can we believe it? Whatever speculative perspective one adopts, concretely the question is whether a person is morally accountable for an occurrence that he neither intended nor had any reason to anticipate. We do one way or another regard persons (with all their determinate attributes) as free and morally responsible. We do not regard them as responsible without limit. Why do we go beyond the ordinary limit here?

If desert is regarded ontologically, the cases that trouble us are distinctive not because their circumstances are especially compelling evidence of normative natural order but the opposite, because they call that assumption peculiarly into question. In a case of felony murder, the death of an innocent person would not have occurred but for commission of the felony. Although we are acquainted with natural fortune and misfortune of all kinds, here the intervention of what we think of as a humanly (that is, self-determined) wrongful act strains the assumption that the death is within a normative order at all; the explicit evidence of normative disorder is too great. By identifying the commission of the felony as the cause of the death and attributing the death to the felon, it is as if we exculpate nature (which is not without some responsibility). ${ }^{83}$ But-for causation, which ordinarily is not enough for an attribution of responsibility, is enough in this case. Although from an ethical perspective, the result contradicts our understanding of desert and seems unjust, from the ontological perspective, punishment of the person who is responsible is restorative of normative order. ${ }^{84}$

82. At least not without some explanation. J.B. Priestley's play, An Inspector Calls, is along these lines. J.B. Priestley, Six Plays 291 (1979).

83. Compare the observation of Joel Feinberg: "When something scandalous has occurred and it is clear that the wrongdoer must be one of a small number of suspects, then the state, by punishing one of these parties, thereby relieves the others of suspicion and informally absolves them of blame." J. Feinberg, Doing and Deserving 105 (1970).

84. It may be helpful to consider the position of the doomed hero in Greek tragedy. Oedipus does everything in his power to avoid the oracle's prediction and fulfills it nevertheless. He and his children suffer beyond any possible personal desert, as we should regard it, because of the wrong of Laius, his father. The end of the tragedy is not a confirmation of the meaninglessness of human 
A similar approach helps to explain the other puzzling doctrines. In cases of self-defense against an innocent aggressor, the critical circumstance that determines who is the survivor is a self-determined act of one of the two persons. Any outcome is affected both by the actions of the two persons and by "natural" circumstances: their resourcefulness, speed, strength, and so forth, as well as factors like the height of the waves, the temperature of the water, or whatever. The significance of describing a wrongful act as "aggression" is precisely that it identifies the act as an alteration of the outcome as it would have been determined by nature and defeats a reference to the normative order of nature itself (including the attributes of the persons) to account for the death. Nature being exculpated, holding the survivor liable follows. Similarly, to allow provocation from a source other than the victim to reduce an intentional killing from murder to voluntary manslaughter would appear to leave a portion of responsibility for the harm undistributed among the human actors; what is in question, however, is not a natural occurrence, but the self-determined, wrongful act of another human being. So also, if the victim of aggression is killed by the act of a third person, who mistakenly goes to the aid of the aggressor; unless the person who intervenes is liable, the occurrence of the harm as a consequence of his mistaken act is too strong evidence of normative disorder.

Although we think of desert as dependent on freedom, from the ontological perspective all that it requires is the causal connection itself; we need only say, as a descriptive matter, that the conduct in question caused, or was a cause of, the harm for which the person is held responsible. If liability follows without more, the result is not more fortuitous than the combination of personal factors that account for the conduct itself. (The victim of the felony had a bad heart; the felon had a bad upbringing.) Coming at the matter in this way, there is not a sharp break between the special, troubling cases and all the straightforward cases of criminal liability; if, as Nozick says, desert does not have to go all the way down, why should it have to go all the way out? The break that we perceive is one of convention, albeit deep convention, only. The criminal law departs from convention in order not to undermine the conventional basis of desert altogether, by calling into question whether a person can ever truly be said to have acted with freedom and responsibility despite the determinate conditions of his existence.

existence-that "chance is all in all," as Jocasta had said-but an affirmation that there is meaning and moral sufficiency. See Sophocles, Oedipus the King (D. Grene trans.) in 2 The Complete Greek Tragedies: Sophocles 9 (D. Grene and R. Lattimore, eds. 1959). For Jocasta's remark, see id. at 52, line 977.

Sometimes it is suggested that a requirement of culpability is justified on the utilitarian ground that it protects us against the fear and disturbance that would be aroused if we knew that we might be found guilty and punished for acts that we could not help but commit. Cf., H.L.A. HART, supra note 2, at $46-47,181-82 ; \mathrm{H}$. PACKER, supra note 2 , at $64-65$. That may be true, although I doubt that most people are concerned concretely about the kind of loss of control that is posited. The possibility of guilt without punishment might feed a more general fear of undeserved harm, no matter what the source. See infra note 85 . From that larger perspective, the fixing of blame in these special cases is reassuring. 
Assigning responsibility as it does in these cases, the criminal law remains close to our ordinary, unreflective judgments. ${ }^{85}$ We do look upon the felon as "in some sense" responsible for his victim's death, whether or not it was an accident. We do tend to think of the person who provokes another person to a homicidal response as "in some sense" getting what he deserves or, as we say, his "just deserts." There is something that calls for requital if a person alters the "natural" odds in a struggle for survival with another person, even though no one deserves to have the natural odds in his favor, or if his mistaken intervention leaves the innocent victim of an act of aggression dead. The doctrines of the criminal law that give effect to these attitudes stand out not because their treatment of responsibility as such seems immediately and obviously defective but because it has consequences and calls for a justification we are unable to provide.

The disturbing feature of Powell v. Texas and other cases in which the defendant claims to be excused from criminal responsibility on the basis of an unrecognized etiological explanation for his conduct can be seen in a similar light. Probably it is easier to comprehend, if not agree with, the conclusion that Powell was responsible than the conclusion that a felon is responsible for a fortuitous death or that a person is culpable despite the necessity that obliges him to take away another person's means to safety. Powell's alcoholism is at least a condition of the person himself. We may be inclined to believe that he voluntarily became an alcoholic, which makes him deserving of something, even if not for the act of public drunkenness as such. We may, therefore, regard the conviction of Powell as problematic or a mistake, but comprehensible nonetheless; whereas the felon's conviction of murder looks like a mistake of another order and incomprehensible. From a nonarbitrary moral standpoint, however, Powell's alcoholism is not different from the circumstances surrounding the felony that produced the death. In both cases, it is simply something that happened.

The disagreement among the Justices had very little to do with how chronic alcoholics would actually be treated. As Justice Black's opinion indicated most clearly, as a practical matter there was little to distinguish Powell's conviction and punishment from a noncriminal disposition. The difference between the theoretical positions of the majority and the dissent is much greater. If Powell is deemed not responsible, we must either clearly identify the special excusing circumstances that take the case out of the realm of freedom or risk undermining desert in every case. For the general premise that conduct is subject to causal order applies universally; and if that is not a normative order in one case for reasons not specific to it, it need not be in any other. Powell's conviction avoids that general problem, but only by brushing aside strong evidence that he in particular really was not able to control his

85. There is abundant psychological evidence that people tend to see normative significance in natural occurrences. See M. Lerner, The Belief in a Just World (1980); Lerner \& Miller, Just World Research and the Attribution Process: Looking Back and Ahead, 85 Psychological Bull. 1030 (1978). Both works contain extensive bibliographies. 
behavior. ${ }^{86}$ Approached in that way, Justice Marshall's statement that it is enough for criminal liability if a person has engaged in "some act . . . some behavior," even if it was "in some sense "involuntary" seems as much a recognition of the fundamental issue as an evasion of it.

\section{$\mathrm{V}$}

\section{ConClusion}

From the foregoing, one may conclude that a satisfactory general theory of criminal responsibility is unattainable. Such a theory, unless it were just a summary description of specific doctrines without explaining them, would have to provide defensible general reasons for regarding some kinds of determinate conditions and circumstances as excluding freedom but not others. It would have to answer the question, "How far down is desert?" But there is in principle no answer. Even if we were able to develop statistical correlations between complex sets of personal characteristics and specific harmful conduct, the most we could achieve would be consistent application of predictions of relative dangerousness. If we were to base the availability of an excuse on such predictions, the lines that we drew would not demarcate a general theory of criminal responsibility; rather, they would indicate abandonment of the concept altogether. ${ }^{87}$

We are led back to the theories of punishment. As justifications for the practice of punishment, neither the retributive theories nor the utilitarian theories are satisfactory. Retribution fails from the utilitarian perspective because desert cannot be demonstrated and punishment for desert alone seems futile. Utilitarianism fails from the retributive perspective because desert cannot be dismissed and punishment for its utility alone seems unjust. The preceding discussion indicates that the source of the problem lies a step further back. Once it has been determined that punishment is deserved, no further justification for carrying out the punishment is necessary or appropriate. Punishment follows directly from desert because only if desert is fulfilled can we be regarded fully as persons-free, morally responsible, and deserving - at all. Our willingness to punish now as desert requires is not only a recognition of freedom; it is also a condition of desert, and therefore freedom, thereafter. Desert without punishment, or moral responsibility without desert, is incoherent as a general rule, even though other considerations may dictate in exceptional cases that punishment not be imposed. The utilitarian argument that desert is an insufficient or unnecessary basis for punishment is in fact a rejection of desert altogether. It

86. See Powell v. Texas, 392 U.S. 514, 555-63 (1968) (Fortas, J., dissenting).

87. We should have to face starkly the puzzle that the concept of criminal responsibility allows us usually to avoid: Ought a prediction of a higher degree of dangerousness make a person more subject to the operation of the criminal law or less? Compare the controversy whether the defense of insanity ought to be available to a "psychopath." E.g., Model Penal Code $\$ 4.01$ (2) commentary at 174-75 (1985); Royal Commission on Capital Punishment, Report, Cmd. 8932, at 135-40 (1953). See generally Morris \& Miller, Predictions of Dangerousness, 6 CRIME and Justice 1 (1985). 
is the argument, in ethical terms, that desert is morally arbitrary or, in ontological terms, that normative natural order is unintelligible. As I have indicated, I do not believe that the argument is incorrect; only our awareness of ourselves and others as persons, acting freely and morally responsible, concludes the issue to the contrary. The utilitarian avoids that response by driving a wedge between desert and punishment and focusing his attack on the latter. But there is no space between them. Punishment or a failure to punish for utilitarian reasons defeats the conditions of desert on which freedom itself depends. It regards persons as things, fit for whatever purposes are acceptable. The utilitarian does not really believe that. If he did, he could not object to the retributive position, as he does, on moral grounds. 